(11) Nordic Council of Ministers

\title{
Northern Lights \\ on TIMSS and \\ PISA 2018
}





\title{
Northern Lights on TIMSS and PISA 2018
}

\author{
TemaNord 2018:524
}




\section{Northern Lights on TIMSS and PISA 2018}

ISBN 978-92-893-5565-O (PRINT)

ISBN 978-92-893-5566-7 (PDF)

ISBN 978-92-893-5567-4 (EPUB)

http://dx.doi.org/10.6027/TN2018-524

TemaNord 2018:524

ISSN 0908-6692

Standard: PDF/UA-1

ISO 14289-1

(c) Nordic Council of Ministers 2018

Cover photo: Unsplash.com

Print: Rosendahls

Printed in Denmark

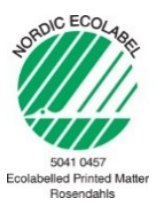

\section{Disclaimer}

This publication was funded by the Nordic Council of Ministers. However, the content does not necessarily reflect the Nordic Council of Ministers' views, opinions, attitudes or recommendations.

\section{Rights and permissions}

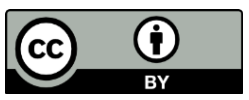

This work is made available under the Creative Commons Attribution 4.0 International license (CC BY 4.0) https://creativecommons.org/licenses/by/4.0

Translations: If you translate this work, please include the following disclaimer: This translation was not produced by the Nordic Council of Ministers and should not be construed as official. The Nordic Council of Ministers cannot be held responsible for the translation or any errors in it.

Adaptations: If you adapt this work, please include the following disclaimer along with the attribution: This is an adaptation of an original work by the Nordic Council of Ministers. Responsibility for the views and opinions expressed in the adaptation rests solely with its author(s). The views and opinions in this adaptation have not been approved by the Nordic Council of Ministers. 
Third-party content: The Nordic Council of Ministers does not necessarily own every single part of this work. The Nordic Council of Ministers cannot, therefore, guarantee that the reuse of third-party content does not infringe the copyright of the third party. If you wish to reuse any third-party content, you bear the risks associated with any such rights violations. You are responsible for determining whether there is a need to obtain permission for the use of third-party content, and if so, for obtaining the relevant permission from the copyright holder. Examples of third-party content may include, but are not limited to, tables, figures or images.

Photo rights (further permission required for reuse):

Any queries regarding rights and licences should be addressed to:

Nordic Council of Ministers/Publication Unit

Ved Stranden 18

DK-1061 Copenhagen K

Denmark

Phone +4533960200

pub@norden.org

\title{
Nordic co-operation
}

Nordic co-operation is one of the world's most extensive forms of regional collaboration, involving Denmark, Finland, Iceland, Norway, Sweden, and the Faroe Islands, Greenland and Åland.

Nordic co-operation has firm traditions in politics, economics and culture and plays an important role in European and international forums. The Nordic community strives for a strong Nordic Region in a strong Europe.

Nordic co-operation promotes regional interests and values in a global world. The values shared by the Nordic countries help make the region one of the most innovative and competitive in the world.

\author{
The Nordic Council of Ministers \\ Nordens Hus \\ Ved Stranden 18 \\ DK-1061 Copenhagen K, Denmark \\ Tel.: +453396 o200 www.norden.org \\ Download Nordic publications at www.norden.org/nordpub
}





\section{Contents}

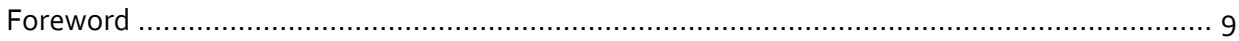

1 TIMSS and PISA in the Nordic countries................................................................ 11

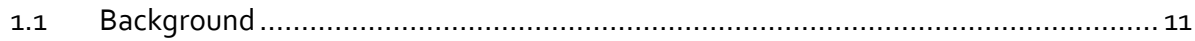

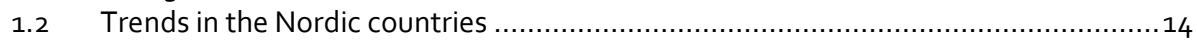

1.3 Use and impact of international studies in the Nordic countries..............................20

1.4 Educational policy development in the Nordic countries .................................. 23

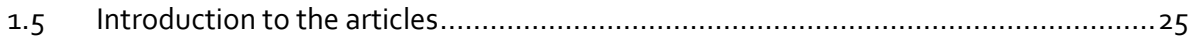

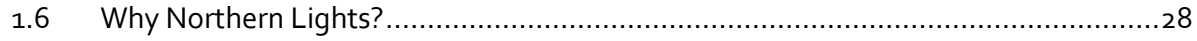

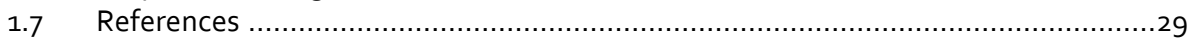

2 Social inequality in student performance in the Nordic countries: A comparison of

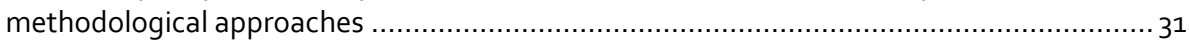

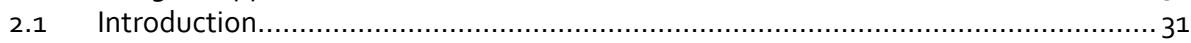

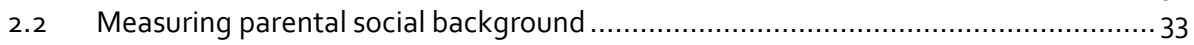

2.3 Parental background measurement in PISA studies ............................................ 35

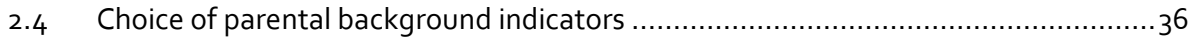

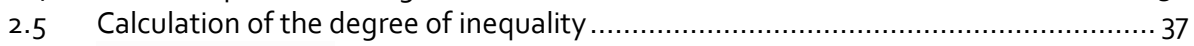

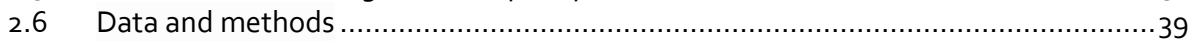

2.7 Different background dimensions and educational inequality across the Nordic

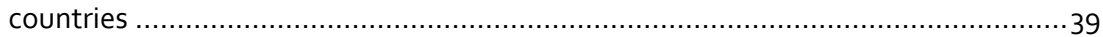

2.8 A different approach for measuring inequality: Quantile regression ......................50

2.9 Conclusions and recommendations for policy and research ...............................5 54

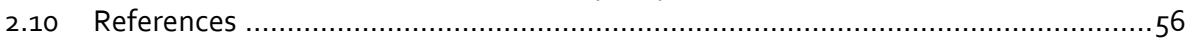

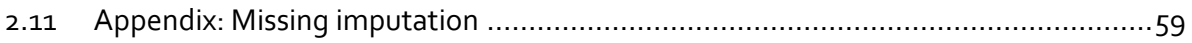

3 The relation of science teachers' quality and instruction to student motivation and

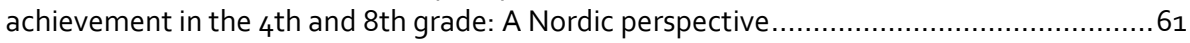

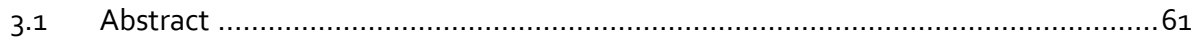

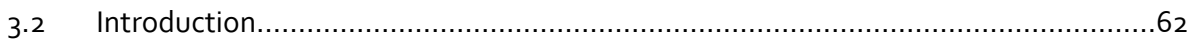

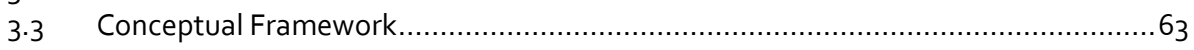

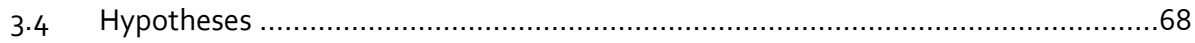

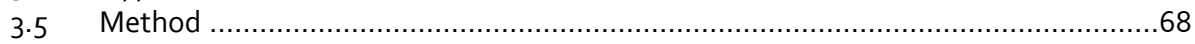

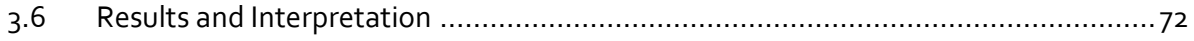

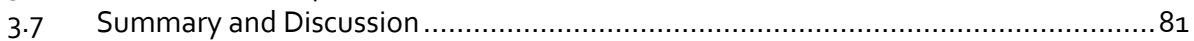

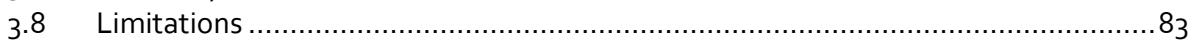

3.9 Conclusions for policy-makers, teacher educators, and researchers....................... 84

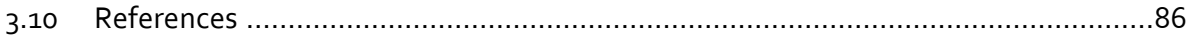

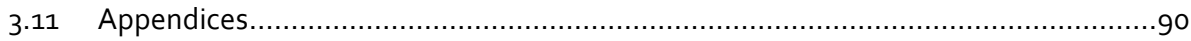


4 Nordic students' interest and self-belief in science ........................................... 95

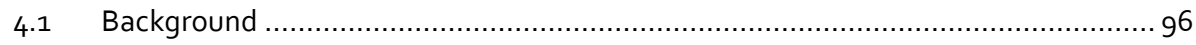

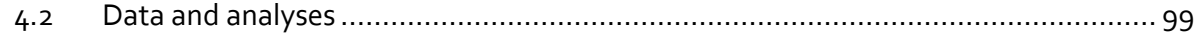

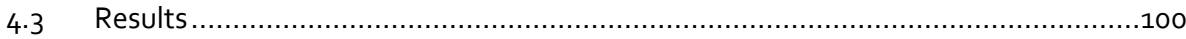

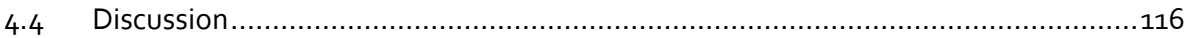

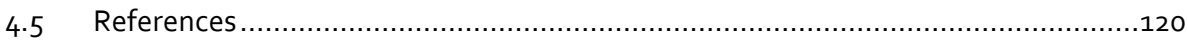

5 PISA, reading literacy, and computer-based assessment ......................................123

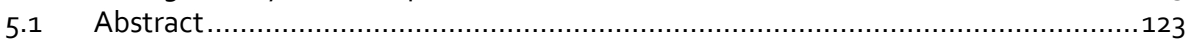

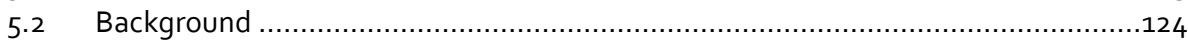

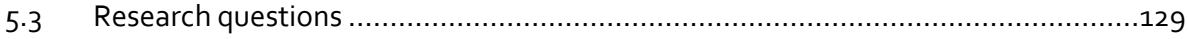

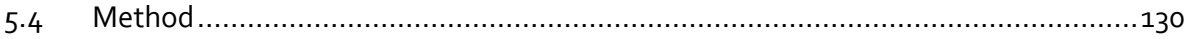

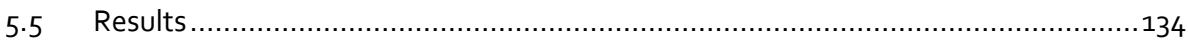

5.6 Internet usage and performance on the reading literacy test .............................135

$5.7 \quad$ Analysis on the item level by response format ..............................................

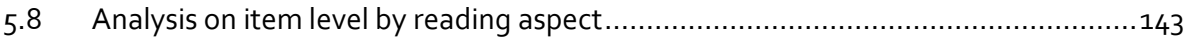

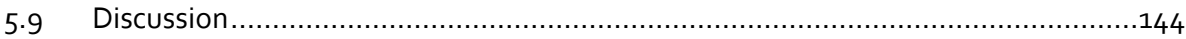

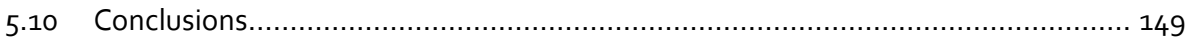

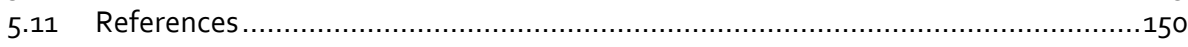

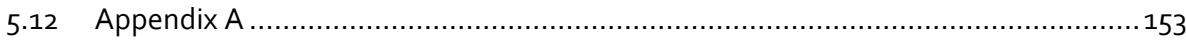

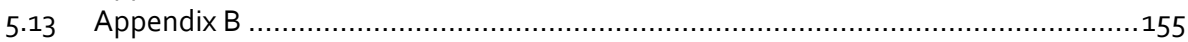

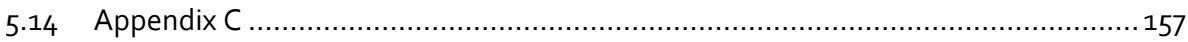

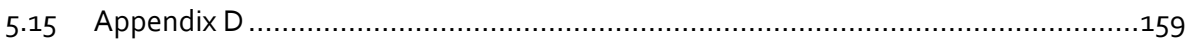

6 Feedback for everybody? - Variations in students' perception of feedback ....................161

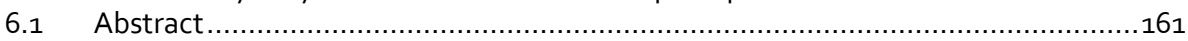

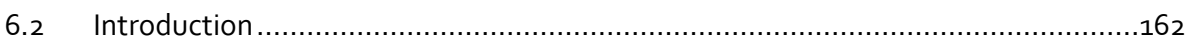

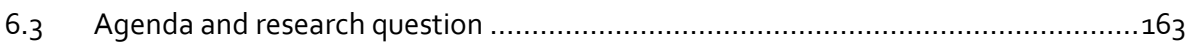

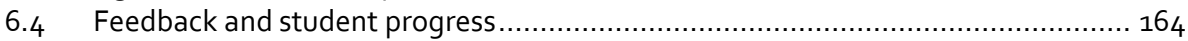

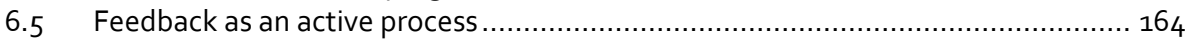

6.6 Variations in students' perception of feedback ............................................. 165

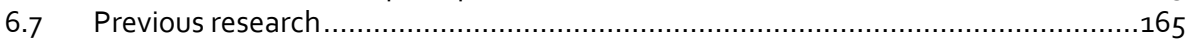

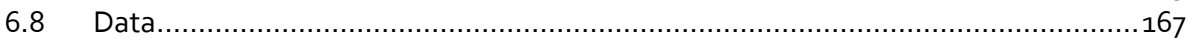

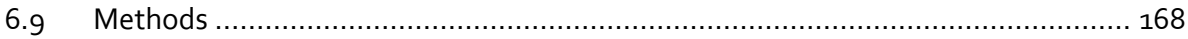

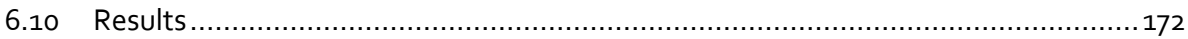

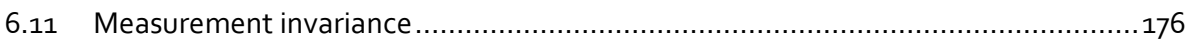

6.12 Conclusion, discussion, and policy implications ......................................... 177

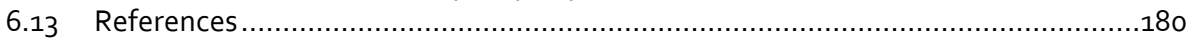

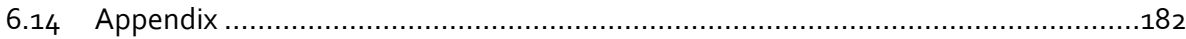


7 The urban advantage in education? Science achievement differences between metropolitan

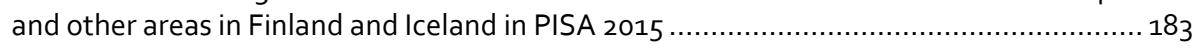

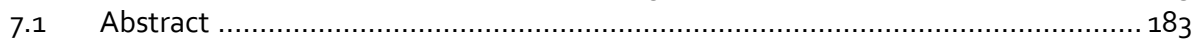

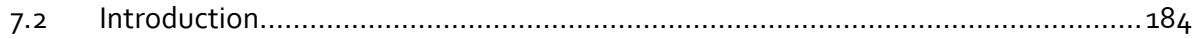

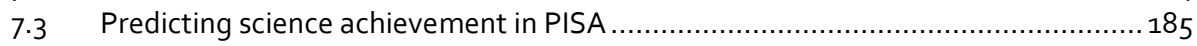

7.4 Capital and urban versus rural or regional................................................. 186

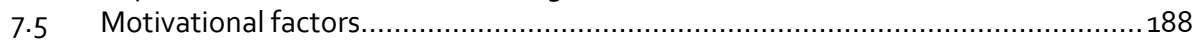

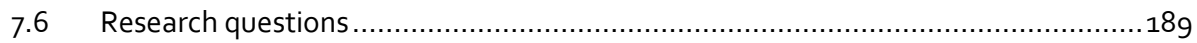

7.7 Regional means of scientific literacy in Finland and Iceland ..............................189

7.8 Background variables for predicting regional differences ............................... 193

7.9 Correlations between background variables and scientific literacy ...................... 197

7.10 Predicting regional mean scores with background variables ...............................200

7.11 Regional differences when controlling for background variables ..........................203

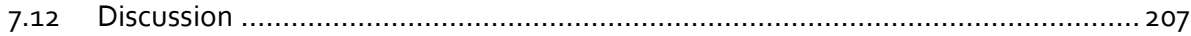

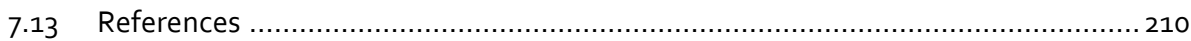

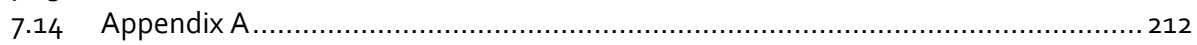

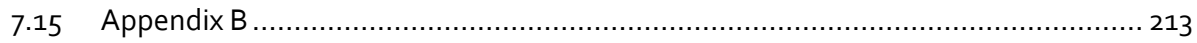

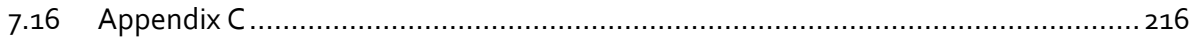

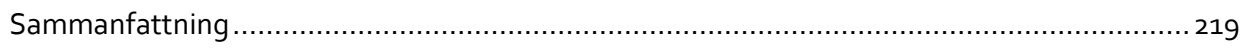




\section{Foreword}

The results from PISA 2015 and TIMSS 2015 were published in November and December 2016. All of the Nordic countries participated in PISA. Denmark, Finland, Norway, and Sweden participated in TIMSS grade 4, and Norway and Sweden participated in TIMSS grade 8 .

The Nordic countries have similarities, but also differences, which makes it interesting and valuable to carry out analyses in a Nordic perspective. In this report, researchers from all of the Nordic countries have performed in-depth analyses on different policy-relevant themes based on the results presented in 2016. The purpose of this report has been to present policy-relevant analyses of TIMSS and PISA in a way that is accessible for policy makers on different levels in the Nordic countries, with the aim to contribute to further development in the education area.

The introductory chapter is an overview of international studies and their significance for the Nordic countries. This chapter is written by Anne-Berit Kavli at the Norwegian Directorate for Education and Training, in cooperation with the Nordic Evaluation Network group. The second chapter deals with social inequality in student performance, and it is a comparison of methodological approaches. The chapter is written by David Reimer, Simon Skovgaard Jensen, and Christian Christrup Kjeldsen. The third chapter about the importance of teachers and their instruction for students' motivation is written by Trude Nilsen, Sigrid Blömeke, and Ronny Scherer. The fourth chapter is written by Magnus Oskarsson, Hanna Eklöf, Marit Kjaernsli, and Helene Sørensen and is a Nordic view on students' interest in science. The fifth chapter analyzes the possible effects of the digitalization of the PISA reading test and is written by Maria Rasmusson and UIf Fredriksson. The sixth chapter by Bent Sortkaer deals with students' perception of feedback. The final chapter asks the question "Urban advantage in education?" and explains the achievement differences in science between metropolitan and other areas in Finland and Iceland in PISA. This chapter is written by Kari Nissinen, Jouni Vettenranta, Juhani Rautopuro, Ragnar F. Ólafsson, and Almar M. Halldórsson. 
The Nordic Evaluation Network group has been acting as the editorial group, led by Anita Wester at the Swedish National Agency for Education. Every paper has also, on two occasions, been reviewed by a panel consisting of Jouni Välijärvi, Finland, Júlíus K. Björnsson, Norway, and Allyson Macdonald, Iceland.

The editorial group wants to thank all of the contributors to this report. Like the previous editions in the Northern Lights series, this publication has received financial support from the Nordic Council of Ministers.

Stockholm in May 2018

Anita Wester

Senior Advisor at the Swedish National Agency for Education

Editor 


\section{Nordic students' interest and self- belief in science}

Magnus Oskarsson, Departement of Mathematics and Science Education, Mid Sweden University.

Marit Kjærnsli, Department of Teacher Education and School Research, University of Oslo.

Helene Sørensen, Danish School of Education, Aarhus University.

Hanna Eklöf, Department of Applied Educational Science, Umeå University.

Modern society requires people with positive attitudes toward science and who have science-related competences. This article will focus on Nordic students' enjoyment in learning science, their self-efficacy in solving scientific problems, and their instrumental motivation to learn science. Findings from PISA 2006 and PISA 2015 show an increasing interest in science in most Nordic countries, and more students in all Nordic countries except Denmark indicate that they expect to have a science-related occupation in the future. At the same time, we can see increased gender differences and greater variation in enjoyment and self-beliefs among students. Enjoyment of learning science and science self-efficacy correlate positively with performance, while instrumental motivation and enjoyment of learning science are associated with an increased likelihood that the student expects to have a science-related career. These findings are discussed in relation to changes in society over the past decade in terms of the visibility and use of science and technology. 


\subsection{Background}

Students' interest in, motivation to learn, and self-beliefs in relation to science are regarded as important factors for their science competence, their future career choices, and their understanding of the role of science in modern society. Student interest and motivation is thus a core issue in educational settings because achievement motivation is assumed to interact with achievement behaviour in important ways (Pintrich \& Schunk, 2002; Wigfield \& Eccles, 2002). It is often claimed, and has been empirically shown, that an interested and highly motivated student performs better in achievement situations, has higher educational aspirations, expends more effort in learning new tasks, and uses more efficient self-regulating strategies compared to less motivated students (Pintrich \& Schunk, 2002). Enjoyment in learning, self-beliefs, and valuing of a subject or task are often seen as parts of a larger interest/motivation construct. Several studies have demonstrated that enjoyment in learning and positive self-beliefs (self-concept, self-efficacy) are positively related to achievement (Bandura, 2010; Krapp \& Prenzel, 2011; Marsh \& Craven, 2006; Skaalvik \& Valas, 1999; Zimmerman, 1992). In contrast, the value students attribute to different subjects has been shown to have a relatively weak relationship with performance compared with other background variables, but there is evidence that value perceptions do predict future achievement choices such as enrolment in mathematics education (Wigfield \& Eccles, 2000).

The importance of interest and motivation variables is also evident in the PISA frameworks. The PISA definition of science literacy recognises that a student's response to a science-related issue requires more than just skills and knowledge; it also depends on how able and "willing" the student is "to engage" with the issue. The student questionnaire in PISA measures students' attitudes towards science in the following three areas: interest in science and technology, environmental awareness, and valuing scientific approaches to enquiry. These three areas were selected for measurement in PISA because a positive attitude towards science, a concern for an environmentally sustainable way of life, and a disposition to value the scientific approach to enquiry were considered characteristic of a scientifically literate individual. Thus, the extent to which individual students are interested in science and recognise its value and implications is considered an important measure of the outcome of compulsory education. If scientific approaches to enquiry are valued, it is possible to 
understand the way scientific claims are supported by the data and by reasoning and to understand the difference between facts and opinions (OECD, 2016a).

However, even if interest in science and the motivation to learn and work with science are perceived as important parts of science literacy in policy documents, education frameworks, and research, this does not automatically result in interested students. Rather, low interest in science and in pursuing a science career has been perceived as a problem in many countries (Bybee \& McCrae, 2011), and it is claimed that school science fails in engaging students and that students think that school science is difficult and not relevant for everyday use or for their future jobs (Schreiner, 2005; Lyons, 2006; Sørensen 2008; Jidesjö, Oscarsson, Karlsson, \& Strömdahl, 2009; Oskarsson, 2011).

The OECD is concerned that the proportions of students who choose careers in science are insufficient for the needs of modern society (OECD, 2016a), and several reports describe a decline in enrolment and graduation rates for science-related fields and perceived shortages of science graduates in the labour market (Gago et al., 2004). Studies of students' interest in science and attempts to raise interest in science and increase recruitment to science-related occupations show the importance of personal relevance for the students (Gago et al., 2004; Osborne \& Dillon, 2010; Teknikdelegationen, 2010).

Previous cycles of PISA and TIMSS have shown that in the Nordic countries the students' interest in science is low compared to other countries in the EU and OECD (Martin, Mullis, Foy, \& Stanco, 2012; OECD, 2007). TIMSS data have further shown that students in grade 4 are more positive towards science than students in grade 8 in most participating countries (Mullis et al., 2016). Oskarsson et al. (2017) showed that the lower interest in science among grade 8 students in Sweden is an important explanation behind Swedish grade 4 students having relative better scores in TIMSS Science than grade 8 students (Oskarsson, Eliasson, \& Karlsson, 2017).

This article focuses on students' interest in science in a Nordic perspective and over time using data from PISA 2006 and PISA 2015. The Nordic perspective has been in focus in other reports as well, and the interested reader is referred to Kjærnsli \& Jensen, 2016; Sørensen \& Dohn 2016a, 2016b. Science was the main subject in PISA in 2006 and PISA 2015, thus data from these two studies provide opportunities to study changes in student perceptions of science over the last decade. Students in these two years were asked about their interest in learning science, their beliefs in their science competence, and the value they placed on learning science. For teachers and policy makers, an informed discussion about the relative importance of different interest variables, about 
changes in student interests, and about possible explanations for observed changes might provide valuable information about the role of interest and motivation in science education.

Today's society faces global challenges such as environment degradation, sustainability, and climate changes. Science, technology, and modern industry are on one hand part of the problem with emissions of carbon dioxide and the use fossil fuels as just one example. On the other hand, science and technology provide possible solutions to many of these problems with solar power plants, windmills, and other sustainable ways of producing energy.

Recently, major changes have taken place in society related to our use of everyday science and new technology. Today 15 -year-old students live in an informationsaturated society that is very different from only a decade ago. Technology has brought changes in how young people communicate with peers and interact with others. The Nordic countries are on top among all countries in the number of computers in school, students' use of computer in their leisure time, and their use of social networks (OECD, 2017), and this has likely had an impact on how students come into contact with and how they value science and technology.

The focus in the current paper is on the Nordic countries, which share many cultural and historical characteristics. They also have similar educational systems, and previous studies using PISA data have shown that students in Denmark, Iceland, Norway, and Sweden tend to follow a "Nordic pattern" in their answers to questions about attitudes. Finland also has many similarities with the other Nordic countries, but it also has some important differences (Kjærnsli \& Lie, 2011). Although it has been shown, that the Nordic countries have several characteristics in common and often are treated as a single entity, it does not mean that they are in fact the same. One of the purposes of the present study was to explore possible differences between the Nordic countries.

\subsubsection{Aims}

Students' attitudes and motivation in relation to science are important for their future career choices and for their understanding of the role of science in modern society. It is therefore important to study how different factors such as instrumental motivation, enjoyment of learning science, and self-efficacy are related to each other and whether these variables can predict students' performance and their future career choice. This 
article reports descriptive findings and relationships between these variables in PISA 2006 and PISA 2015 for the Nordic countries and the OECD as a whole.

\subsubsection{Research questions:}

- What levels of self-reported enjoyment in learning science, science self-efficacy, and instrumental motivation do students in the Nordic countries report in PISA? Has their interest in and motivation to learn science changed over time, and are there differences between the Nordic countries?

- Are there differences between boys and girls in terms of interest in and motivation to learn science and in their expectations of pursuing a science career, and have possible gender differences changed over time in the Nordic countries?

- How are different interest variables related to each other, and how do these variables affect science performance and students' willingness to consider a career in science?

\subsection{Data and analyses}

We used student questionnaire and performance data from all Nordic countries from PISA 2006 and 2015. The choice arose from our focus on science, and science was the main subject in both years. The sample in the Nordic countries was in total 22,170 15year-old students in 2006 and 27,331 15-year-old students in 2015 (OECD, 2009, 2016b).

First, we selected relevant data to answer our research questions from the PISA databases and processed them to provide the dataset for our detailed analysis. In order to be able to study changes over time, we chose to work with the three interest/motivation constructs that were assessed in both 2006 and 2015 (enjoyment of learning science, instrumental motivation, and science self-efficacy) along with an openended item asking the students about their future career expectations. We sought to identify changes from 2006 to 2015, differences between boys and girls, and changes in response patterns for individual items as well as relationships between the respective interest/motivation constructs and student's performance in science in PISA. We also investigated the interrelationships between the different interest indices, their effect on performance when modelled together rather than separately, and their effect on the likelihood that the student is interested in a science-related occupation. In the analyses, 
we used the motivation/interest scales, or "indices", already provided in the PISA databases. All index scales in 2015 were set to allow for comparisons with the corresponding index scales in PISA 2006 and are thus suitable for trend analyses (OECD, 2016b).

The index value for the average OECD student was zero the first time it was calculated (in 2006) and had a standard deviation of 1 . This means that two thirds of the OECD students' index values would be between the values of -1 and 1. It is important to point out that negative values on the index do not imply that students responded negatively. Instead, a negative value means that the student's response had a value below the average response across the OECD countries. Likewise, students with positive values on the index are those who responded more positively than an average student in the OECD (see more details in Annex 1 in the OECD report).

In all analyses, student weights and all plausible values were used (for more information about the use of weights and plausible values as estimates of student proficiency, see OECD, 2009, 2016b). In the processing and analysis of the data, we used the Excel, SPSS/IEA IDB Analyzer, and Mplus 7.2 (Muthén \& Muthén, 1998-2002) software packages. Both the IDB Analyzer and Mplus are analytical tools that are suitable for use with PISA-type data. In particular, Mplus is suitable for so-called multilevel analysis. Because students participating in PISA are clustered in schools, the school level is a source of variation that might be relevant to consider in the analyses. A general rule of thumb is that school-level variation is considered non-trivial if it accounts for more than $5 \%$ of the total variation. Two-level analyses performed in Mplus, however, suggested that only a small amount (1\%-4\%) of the variation in the interest indices was at the school level. Therefore, we decided to continue with and report only single-level analyses, but with standard errors adjusted to account for the clustered structure of the data. The same result was obtained regardless of the software used, and below the SPSS output (obtained by using the IDB Analyzer) is presented.

\subsection{Results}

PISA distinguishes between two forms of motivation for learning science. Students might learn science because they like it and find it interesting and/or because they think that science can be useful in their lives. This is the background for investigating the students' desire to learn and their instrumental motivation supplemented with science- 
related career expectations. In the first part of the results section, we will present the results for three of the constructs in PISA, enjoyment of learning science, instrumental motivation to learn science, and science self-efficacy. We will start with an international outlook regarding one of the constructs, enjoyment of learning science, and then focus on the Nordic perspective for all three constructs. In the second part of the results section, we will present findings for the Nordic countries for the open-ended question about career expectations. Both the constructs and the open-ended questions were identical in PISA 2006 and PISA 2015. For each construct, we will present the index values (mean and standard deviation) for the Nordic countries and the OECD, respectively, and we will explore gender differences and changes from PISA 2006 to PISA 2015. In addition to analysing these constructs one by one, we also performed a correlation analysis and a multiple regression analysis to explore the relationships between the three constructs and their relative effects on the student's scores in science when modelled together. The results of this analysis are presented at the end of the first part of the results section. Furthermore, we present results for the students' expectations of science-related careers, and in connection with this we provide the results of a logistic regression analysis with the different interest variables as predictors of science career expectations.

\subsubsection{Enjoyment of learning science}

The construct, enjoyment of learning science is measured in PISA by five statements. The students were asked how much they disagreed or agreed with each statement, and the response categories were "strongly disagree", "disagree", "agree", and "strongly agree":

- I generally have fun when I am learning science topics.

- I like reading about science.

- I am happy working on science.

- I enjoy acquiring new knowledge in science.

- I am interested in learning about science.

Figure 1 shows the index values for enjoyment of learning science for the OECD countries in order to show the results from the Nordic countries in an international perspective. 
The figure consists of two parts, with the upper part showing the index value for both PISA 2006 and PISA 2015, while the lower part of the figure shows the difference between the index values in these two studies (PISA 2015 minus PISA 2006). Positive values therefore show that students responded more positively to these statements in 2015. We think it is important to see these two figures together. A positive value of the index shows that the country's students enjoy science more than the average for students in the OECD.

Figure 1 Index of students' enjoyment of learning science for PISA 2015 and PISA 2006
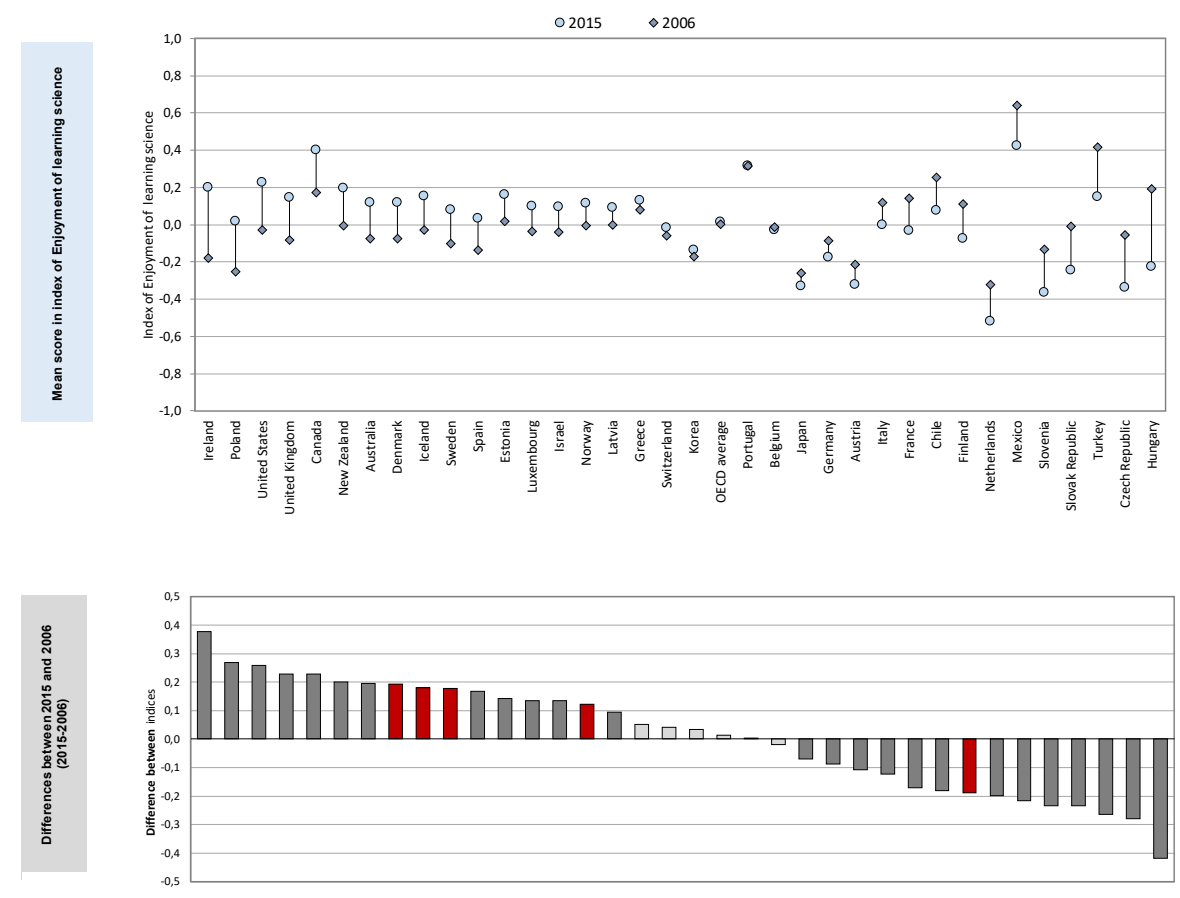

Note: Results are given for OECD countries. Statistically significant differences are shown in a darker tone. Countries are ranked in descending order of the change in the index of students' enjoyment of learning science between 2006 and 2015. The Nordic countries are highlighted in red.

The bottom part of figure 1 shows that in 16 of the OECD countries, the students' enjoyment of learning science improved significantly. The greatest increase of the index was in Ireland, followed by countries such as Poland, the US, the UK, and Canada. 
However, when looking in the first part we see that despite the significant increase, the actual index value for Poland in PISA 2015 was still lower than in many of the other countries. In Portugal, there was no change between the two assessments, but the index value was still very high in both assessments compared to most other countries. The largest decreases were in Hungary, the Czech Republic, and Slovakia. Students in the Nordic countries, with the exception of Finland, reported becoming more interested in science. We will discuss the Nordic results in greater detail below.

Figure 2: Enjoyment of learning science in PISA 2015 by gender
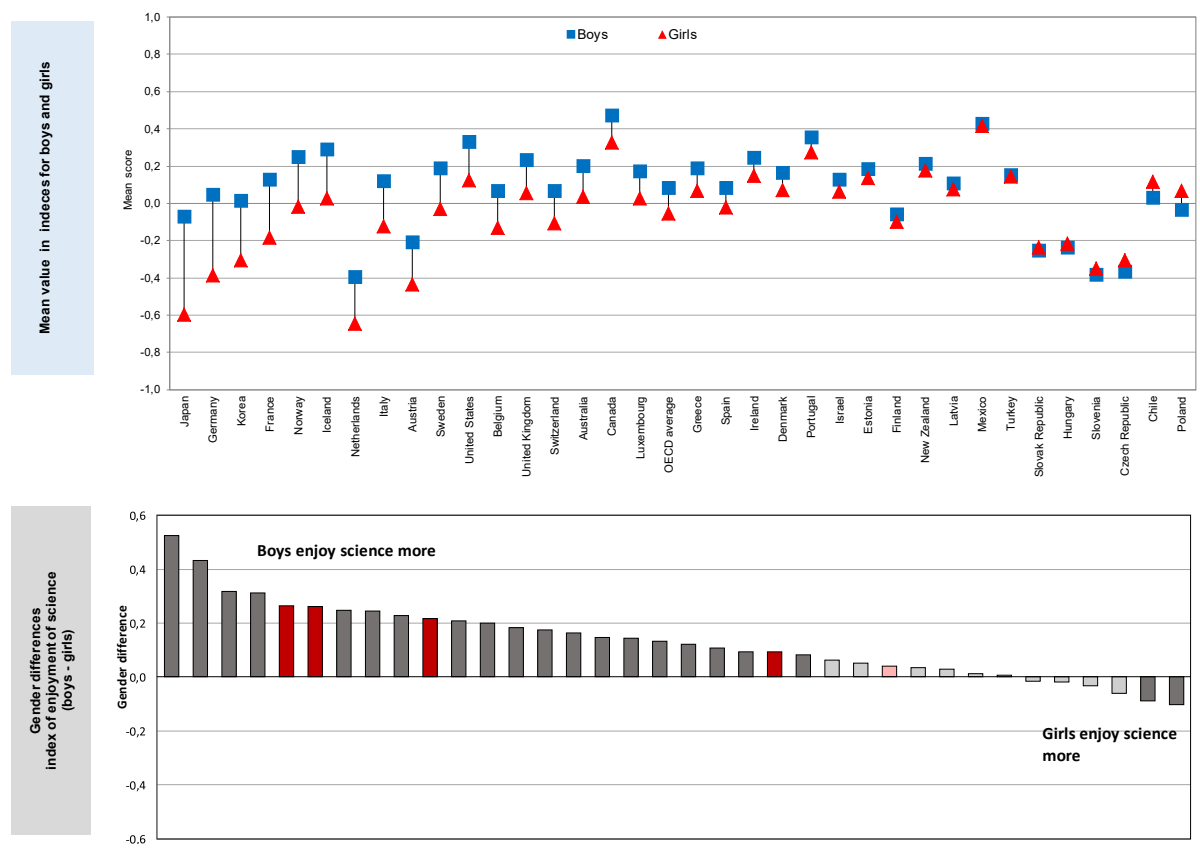

Note: Results are given for OECD countries. Statistically significant differences are shown in a darker tone. Countries are ranked in descending order of the change in the index of students' enjoyment of learning science for boys minus girls. The Nordic countries are highlighted in red.

Figure 2 shows the index of enjoyment of learning science for girls and boys separately. This figure also consists of two parts. The upper part shows the index values for boys and girls in PISA 2015, and the lower part shows the differences between boys and girls. Positive values on the lower part mean that boys responded more positively than girls to the statements in this construct. Figure 2 clearly shows that boys reported enjoying 
learning science more than girls in most of the OECD countries. The greatest gender except Finland. Only in Poland and Chile did girls report enjoying science significantly more than boys.

In the following, we will focus more closely on the Nordic perspective and start with the same index about enjoyment that was described above. Table 1 shows the results for the index of enjoyment of learning science in the Nordic countries.

Table 1: Results for the index enjoyment of learning science. Changes from PISA 2006 to PISA 2015, gender differences, and changes in the science score per unit of this index

\begin{tabular}{|c|c|c|c|c|c|c|c|c|c|}
\hline & \multicolumn{4}{|c|}{ Index of enjoyment of science } & \multirow{3}{*}{$\begin{array}{c}\text { Change in } \\
\text { science } \\
\text { index }\end{array}$} & \multicolumn{2}{|c|}{ Gender differences } & \multicolumn{2}{|c|}{$\begin{array}{l}\text { Change in the science } \\
\text { score per unit of this index }\end{array}$} \\
\hline & \multicolumn{2}{|c|}{ PISA 2006} & \multicolumn{2}{|c|}{ PISA 2015} & & PISA 2006 & PISA 2015 & PISA 2006 & PISA 2015 \\
\hline & Mean & S.D. & Mean & S.D. & & Boys-girls & Boys-girls & & \\
\hline Denmark & -0.07 & 0.98 & 0.12 & 1.14 & 0.19 & 0.01 & 0.09 & 31 & 26 \\
\hline Finland & 0.11 & 0.89 & -0.07 & 1.01 & -0.19 & -0.18 & 0.04 & 32 & 30 \\
\hline Iceland & -0.03 & 1.13 & 0.15 & 1.26 & 0.18 & 0.20 & 0.26 & 40 & 24 \\
\hline Norway & -0.01 & 1.08 & 0.12 & 1.20 & 0.12 & 0.24 & 0.27 & 35 & 29 \\
\hline Sweden & -0.10 & 1.04 & 0.08 & 1.26 & 0.18 & 0.01 & 0.22 & 33 & 27 \\
\hline OECD avg. & -0.00 & 1.03 & 0.02 & 1.17 & 0.01 & 0.07 & 0.13 & 30 & 25 \\
\hline
\end{tabular}

Note: Statistically significant values are indicated in italic. Standard error of the index for the Nordic countries is 0.02 except for Sweden where it is 0.03 .

As we already have seen, the results show that students in the Nordic countries, except in Finland, reported higher enjoyment of learning science than the average in the OECD countries. In these countries, the students reported a significantly greater enjoyment of learning science in 2015 than in 2006, while there was a significant decrease in Finland. The results clearly show that enjoyment of learning science was positively related to the science score. In 2006, the change in science score per unit of this index was high for all the Nordic countries and was highest for Iceland. In 2015, the relationship with performance was weaker in all Nordic countries, and the decrease was particularly evident in Iceland, although the coefficients were still positive and significant. Enjoyment of learning science seems therefore to be an important aspect for learning science.

In all of the Nordic countries, the boys on average expressed a higher enjoyment of learning science compared to the girls, except in Finland where there was no significant difference. The gender differences were greatest in Norway, Iceland, and Sweden. 
Table 1 also shows that the standard deviation was greater in 2015 than in 2006, which means that there was an increase in the variance of this index for the Nordic countries and on average for the OECD in 2015 compared to 2006. To determine if more students chose the two extreme categories of "strongly disagree" and "strongly agree", we made an investigation of students' answers to all the individual questions in this construct for all response categories. Figure 3 illustrates this, showing the percentage of students who strongly agreed and strongly disagreed, respectively, with the statement I am interested in learning about science.

Figure 3: Results for the statement "I am interested in learning about science" showing the percentage of students who answered "strongly agree" and who answered "strongly disagree". Statistically significant differences are described in the text

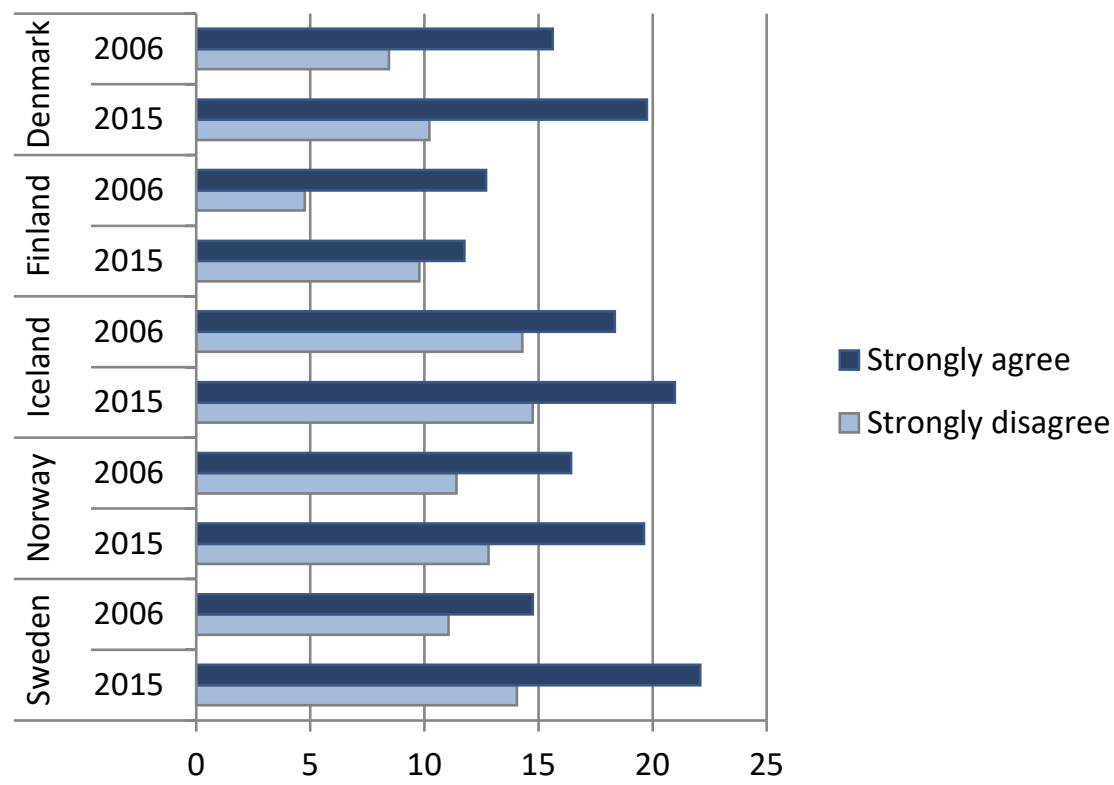

In all of the Nordic countries, except in Finland, more students responded "strongly agree" to all statements in 2015 than in 2006. The differences were statistically significant. The numbers of students who responded "strongly disagree" also increased in the Nordic countries but the differences were statistically significant only in Sweden and in Finland. 


\subsubsection{Instrumental motivation to learn science}

Instrumental motivation to learn science is defined as students' motivation to learn science because it is us eful for them and for their future education and careers (Wigfield \& Eccles 2000). The statements in PISA are designed to measure the extent to which the students perceive science as relevant and useful for them in connection to their expectations about educational careers. The statements are:

- Making an effort in my school science subject(s) is worth it because this will help me in the work I want to do later on.

- What I learn in my school science subject(s) is important for me because I need this for what I want to do later on.

- Studying my school science subject(s) is worthwhile for me because what I learn will improve my career prospects.

- Many things I learn in my school science subject(s) will help me to get a job.

The students could respond "strongly agree", "agree", "disagree", or "strongly disagree" to these statements.

Table 2: The index of instrumental motivation to learn science. Changes from PISA 2006 to PISA 2015, gender differences, and the change in the science score per unit of this index

\begin{tabular}{|c|c|c|c|c|c|c|c|c|c|}
\hline & \multicolumn{4}{|c|}{ Index of science self-efficacy } & \multirow{3}{*}{$\begin{array}{l}\text { Change in } \\
\text { science index } \\
2015^{-2006}\end{array}$} & \multicolumn{2}{|c|}{ Gender differences } & \multicolumn{2}{|c|}{$\begin{array}{l}\text { Change in the science } \\
\text { score per unit of this } \\
\text { index }\end{array}$} \\
\hline & \multicolumn{2}{|c|}{ PISA 2006} & \multicolumn{2}{|c|}{ PISA 2015} & & PISA 2006 & PISA 2015 & PISA 2006 & PISA 2015 \\
\hline & Mean & S.D. & Mean & S.D. & & Boys-girls & Boys-girls & & \\
\hline Denmark & 0.04 & 0.97 & 0.04 & 1.00 & 0.00 & -0.08 & -0.03 & 18 & 12 \\
\hline Finland & -0.22 & 0.89 & 0.16 & 0.92 & 0.37 & -0.13 & -0.04 & 31 & 18 \\
\hline Iceland & 0.09 & 1.11 & 0.22 & 1.04 & 0.14 & 0.09 & 0.03 & 28 & 9 \\
\hline Norway & -0.16 & 0.95 & 0.11 & 0.94 & 0.27 & 0.02 & -0.05 & 22 & 13 \\
\hline Sweden & -0.05 & 0.98 & 0.26 & 0.97 & 0.31 & 0.02 & 0.04 & 26 & 14 \\
\hline OECD avg. & 0.01 & 0.98 & 0.14 & 0.98 & 0.13 & 0.02 & 0.04 & 18 & 9 \\
\hline
\end{tabular}

Note: Statistically significant values are indicated in italic. Standard error (S.E.) of the index for the Nordic countries is 0.02 .

The results in Table 2 show that there has been a noteworthy and significant increase in instrumental motivation from PISA 2006 in all of the Nordic countries except in 
Denmark where the result was unchanged. Hence, students in the Nordic countries, except Denmark, seem to have perceived science as being more useful in PISA 2015 compared to how the students in PISA 2006 responded to the same statements. Gender differences for the index were small and not statistically significant in any of the Nordic countries. Instrumental motivation for science had a weak positive correlation with the science score in the Nordic countries and for the average in the OECD, especially when compared to 2006 .

\subsubsection{Self-efficacy in science}

Science self-efficacy is defined as the extent to which students believe in their own ability to handle science tasks effectively and to overcome difficulties. For each statement in this scale, students are asked to rate whether they "can do this easily", "do it with a bit of effort", "would struggle to do it on their own", or "couldn't do it". The questions are expressed as follows:

- Recognize the science question that underlies a newspaper report on a health issue.

- Explain why earthquakes occur more frequently in some areas than in others.

- Describe the role of antibiotics in the treatment of disease.

- Identify the science question associated with the disposal of garbage.

- Predict how changes to an environment will affect the survival of certain species.

- Interpret the scientific information provided on the labelling of food items.

- Discuss how new evidence can lead you to change your understanding about the possibility of life on Mars.

- Identify the better of two explanations for the formation of acid rain.

Table 3 summarizes the index, gender differences, changes from 2006 to 2015, and the correlation between the index and students performance in science. 
Table 3: Index of science self-efficacy, gender differences, changes from 2006 to 2015, and changes in the science score per unit of this index

\begin{tabular}{|c|c|c|c|c|c|c|c|c|c|}
\hline & \multicolumn{4}{|c|}{ Index of science self-efficacy } & \multirow{3}{*}{ 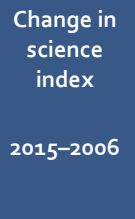 } & \multicolumn{2}{|c|}{ Gender differences } & \multicolumn{2}{|c|}{$\begin{array}{l}\text { Change in the science } \\
\text { score per unit of this } \\
\text { index }\end{array}$} \\
\hline & \multicolumn{2}{|c|}{ PISA 2006} & \multicolumn{2}{|c|}{ PISA 2015} & & PISA 2006 & PISA 2015 & PISA 2006 & PISA 2015 \\
\hline & Mean & S.D. & Mean & S.D. & & Boys-girls & Boys-girls & & \\
\hline Denmark & -0.08 & 1.02 & 0.08 & 1.24 & 0.16 & 0.24 & 0.37 & 41 & 22 \\
\hline Finland & 0.02 & 0.93 & -0.04 & 1.18 & -0.07 & 0.10 & 0.26 & 41 & 23 \\
\hline Iceland & 0.14 & 1.16 & 0.24 & 1.52 & 0.11 & 0.34 & 0.50 & 38 & 15 \\
\hline Norway & 0.12 & 1.06 & 0.19 & 1.27 & 0.07 & 0.18 & 0.23 & 33 & 22 \\
\hline Sweden & -0.07 & 1.03 & 0.05 & 1.29 & 0.12 & 0.21 & 0.39 & 38 & 21 \\
\hline OECD avg. & 0.00 & 1.04 & 0.04 & 1.30 & 0.04 & 0.12 & 0.20 & 38 & 18 \\
\hline
\end{tabular}

Note: Statistically significant values are indicated in italic. Standard error of the index for the Nordic countries is 0.02 ( 0.03 for Sweden) in PISA 2006.

There was a statistically significant increase in this index for all countries except Finland, which means that the students in the four countries had gained confidence in their ability to answer scientific problems. There was also a growing difference between students in general. Table 3 shows that the standard deviation was greater in 2015 than in 2006. That means that there was an increase in variance of this index for the Nordic countries and on average for the OECD countries in 2015 compared to 2006, meaning increased differences between different students' answers. There was furthermore a large gender gap in this index, which means that girls reported feeling it hard to deal with science-related topics. There was a positive correlation between the index of selfefficacy and science scores for the Nordic countries and for the OECD on average, but as for the other two constructs, the correlations were weaker in 2015 compared to 2006.

\subsubsection{Enjoyment, motivation, self-efficacy, and science performance}

So far, we have described the three interest/motivation variables one by one and looked at the relationship with performance without considering the impact of other variables simultaneously. It is, however, reasonable to expect that these variables tap partly the same constructs and share common variance. To explore how the different interest variables might be related to each other and their relative importance in predicting science performance when modelled together rather than in isolation, as well as to look 
for possible changes in these relationships over time, we performed a correlation analysis and a multiple regression analysis.

The correlation analysis suggested that all three interest/motivation variables were positively and significantly related to each other in both 2006 and 2015. Hence, a student who enjoyed science was more likely to believe that he or she was competent in science and was more likely to be motivated to learn science. However, the strength of the correlations was low to moderate. As a background for interpreting these results, have in mind that two completely unrelated variables have a correlation of o and two perfectly related variables have a correlation of 1 . The correlations between the different interest indices for the five Nordic countries for PISA 2006 and PISA 2015 ranged from $r=0.2$ for the correlation between instrumental motivation and science selfefficacy in Denmark in 2015 to $r=0.6$ for the correlation between instrumental motivation and enjoyment of learning science in Iceland in 2006. The pattern of correlations was similar for all Nordic countries, with somewhat weaker relationships between science self-efficacy and instrumental motivation, and somewhat stronger relationships between enjoyment of learning science and self-efficacy and between enjoyment of learning science and instrumental motivation. The pattern of correlations also looked similar over time, although correlations were generally lower in 2015 compared to 2006.

We next performed a multiple linear regression analysis to determine if and to what extent the different interest indices still predicted performance (as suggested by Tables 1-3) when modelled together and to study whether there were similarities between 2015 and 2006. The results of this analysis suggested that in both 2015 and 2006 in all Nordic countries enjoyment of learning science and science self-efficacy were positively and significantly related to science performance; however, a pattern could be seen where the effect of self-efficacy was weaker in 2015 than in 2006. In contrast, the effect of instrumental motivation on science performance was weak and in several cases not significant when controlling for the other two variables (Table 4). The pattern was similar for all Nordic countries in both 2015 and 2006. Overall, however, the model explained less of the variation in performance in 2015 compared to 2006. The amount of variance in performance that could be accounted for by the regression model was smaller for 2015 compared to 2006, as evidenced by the $\mathrm{R}^{2}$ values, and this decrease was particularly visible in Iceland. Thus, even if students in general reported more interest and motivation for learning science, there might be aspects of this increased interest that were not as strongly related to performance in 2015 compared to 2006, 
and lower-performing students might, for example, have reported high levels of selfefficacy without this being evidenced in their performance on the PISA test, and there might be other variables that are also important for explaining the science performance of modern youth.

Table 4: Regression coefficients and amount of variance explained ( $\left.R_{2}\right)$, science performance as the dependent variable. Results from PISA 2006 and PISA 2015 for the Nordic countries

\begin{tabular}{|c|c|c|c|c|c|c|c|c|}
\hline \multirow{2}{*}{$\begin{array}{l}\text { Predicted variable: } \\
\text { Science performance } \\
\text { Country and year }\end{array}$} & \multicolumn{2}{|c|}{$\begin{array}{l}\text { Instrumental } \\
\text { motivation }\end{array}$} & \multicolumn{2}{|c|}{$\begin{array}{l}\text { Enjoyment of } \\
\text { learning science }\end{array}$} & \multicolumn{2}{|c|}{ Science self-efficacy } & \multicolumn{2}{|c|}{$\begin{array}{c}\text { All variables } \\
\mathbf{R}^{2}\end{array}$} \\
\hline & 2006 & 2015 & 2006 & 2015 & 2006 & 2015 & 2006 & 2015 \\
\hline Denmark & 0 & -1 & 14 & 19 & 34 & $15 *$ & .22 & .15 \\
\hline Finland & 13 & $3^{*}$ & 12 & $22 *$ & 32 & $16 *$ & .24 & .14 \\
\hline Iceland & 2 & o & 25 & 20 & 24 & $8^{*}$ & .28 & .14 \\
\hline Norway & 0 & -4 & 24 & 24 & 22 & $14 *$ & .21 & .17 \\
\hline Sweden & 7 & $-2 *$ & 15 & $23 *$ & 27 & $13 *$ & .21 & .15 \\
\hline
\end{tabular}

Note: Statistically significant regression coefficients are indicated in italic. When the difference between the coefficients within a country is significant between 2006 and 2015, this is indicated with an asterisk on the 2015 value.

Italic $=p<.01$, meaning that the value is statistically significant at the $1 \%$ level.

* = change in coefficient between 2006 and 2015 is significant.

The values in Table 4 are b-coefficients from the regression analysis, together with $\mathrm{R}^{2}$, which is a measure of how much of the variation in the data can be explained by the regression model. The b-coefficients can be interpreted as follows. A one-step increase of the value in the respective interest index (for example, enjoyment of learning science) will result in a performance increase corresponding to the value of the b-coefficient. An increase in the enjoyment of learning science index in Denmark in 2006 from 0.5 to 1.5 will have a positive effect on science performance, which will increase the PISA score by around 14 points according to the model (an increase of 30-40 points on the PISA test is generally regarded as corresponding to one additional year of schooling). An increase in the instrumental motivation index in Denmark 2006, on the other hand, will not have any significant effect on science performance according to the model. Therefore, even if instrumental motivation is significantly related to performance when other interest variables are not accounted for, this relationship disappears when controlling for the other interest variables. This result was obtained for all Nordic countries and for both years, except for Finland in 2006. We also tested whether the 
regression coefficients were significantly different $(p<.01)$ between the two years and in all Nordic countries, and the b-coefficient for science self-efficacy was significantly smaller (although still significant) in 2015 than in 2006. For Sweden and Finland, there were also significant changes in the coefficients for the variables instrumental motivation and enjoyment of learning science, while this was not the case in Denmark, Iceland, or Norway. Thus, in the Nordic countries, in particular the effect of science selfefficacy on science performance was significantly lower in 2015 than in 2006. At the same time, students in all Nordic countries except Finland reported higher levels of science self-efficacy in 2015 (Table 3).

In summary, a student who enjoys science and trusts in their ability to solve sciencerelated questions (self-efficacy) tends to score better on the PISA test. This was true in 2006 as well as in 2015 .

\subsubsection{Science-related career expectations}

Over the past several years, there has been an emphasis on the importance of recruiting more individuals to education and careers in science and technology. Therefore, the PISA background questionnaire asks about the students' expectations about careers in relation to science and technology. In both PISA 2006 and PISA 2015, the students were asked to respond to an open-ended question: What kind of job do you expect to have when you are about 30 years old?

The students' responses were given in their own words and could be any job title or description. All responses were classified according to the International Standard Classification of Occupations (ISCO-08). However, many students at this age are unsure of what profession they expect to have, and many students did not answer or indicated that they were undecided. In this context we focused only on student responses that were well-defined expectations of a science-related career, defined as those career expectations that require the study of science beyond compulsory education. These responses were categorized into the following major groups: science and engineering professionals; health professionals; science-related technicians and associated professionals; and information and communication technology professionals (see OECD, 2016a, Annex A1 for more details). 
Figure 4: Percentages of students who in 2015 expect to work in different science-related professional and technical occupations when they are 30 years old. Results based on students' self-reports

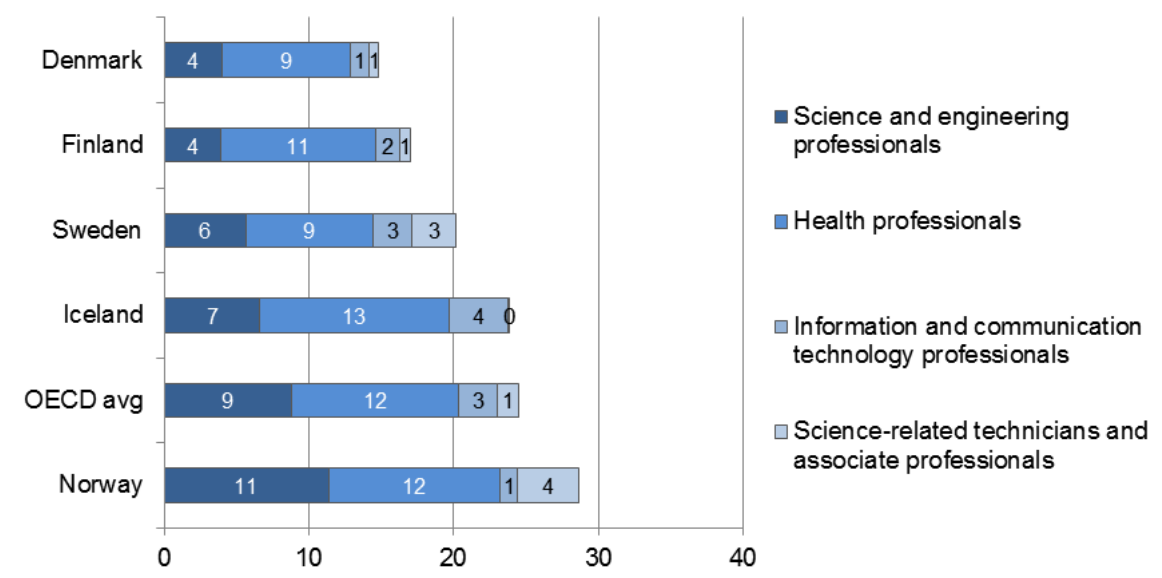

Figure 4 shows that on average almost $24 \%$ of the students across the OECD countries reported in PISA 2015 that they expected to work in a science-related occupation. Although all 15-year-olds do not have such clear ideas as to what they want to work with in the future, the expectation of a future with relation to science and technology might have an influence on students' commitment to science learning in the actual situation in the science classroom. One interesting finding is that relatively few students reported that they were aiming for a job as information and communication technology professionals. This might be because the ISCO codes are quite detailed in this area, and many students answer more generally such as "engineer" and not a specific occupation like "computer scientist", "software developer", "applications programmer", etc. Another plausible explanation might be that students' interest in information and communication technology is more related to entertainment than to a future job. 
Figure 5: Percentage of students in PISA 2006 and PISA 2015 who expected to work in science-related professional and technical occupations when they are 30 years old. Results based on students' selfreports

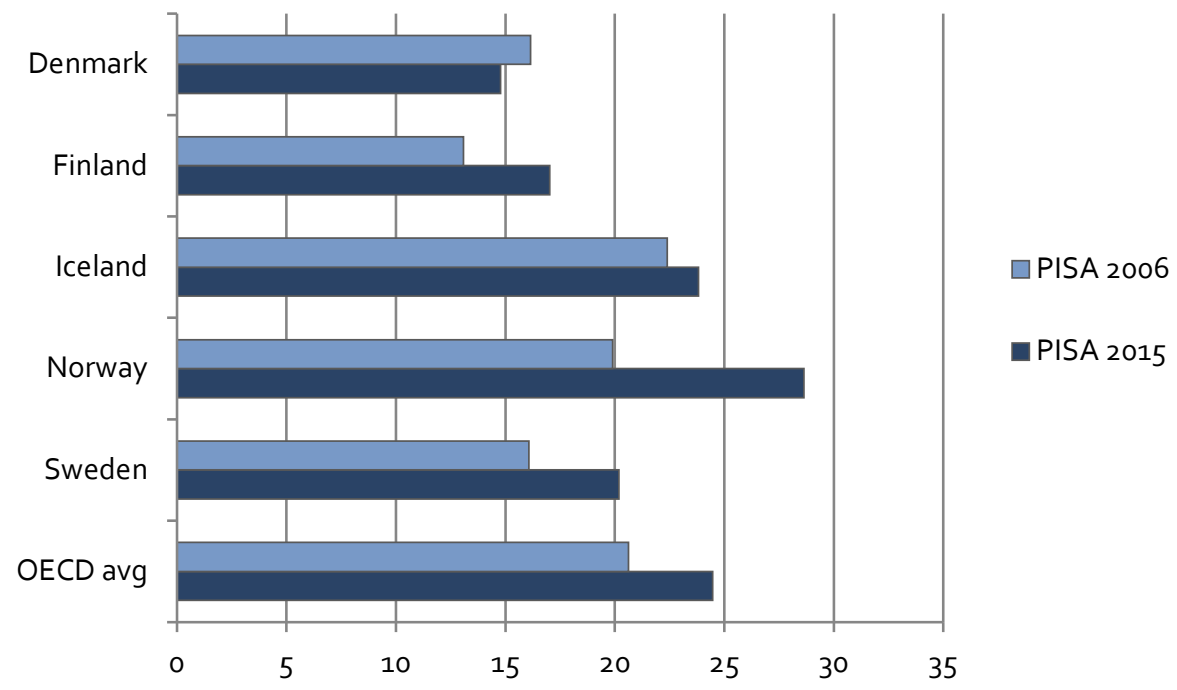

The percentage of students who expected to work in science-related professional and technical occupations when they are 30 increased from PISA 2006 to PISA 2015 in all Nordic countries except Denmark (Figure 5). 
Figure 6: Percentage of students expecting to work as science and engineering professionals and health professionals by gender in 2015

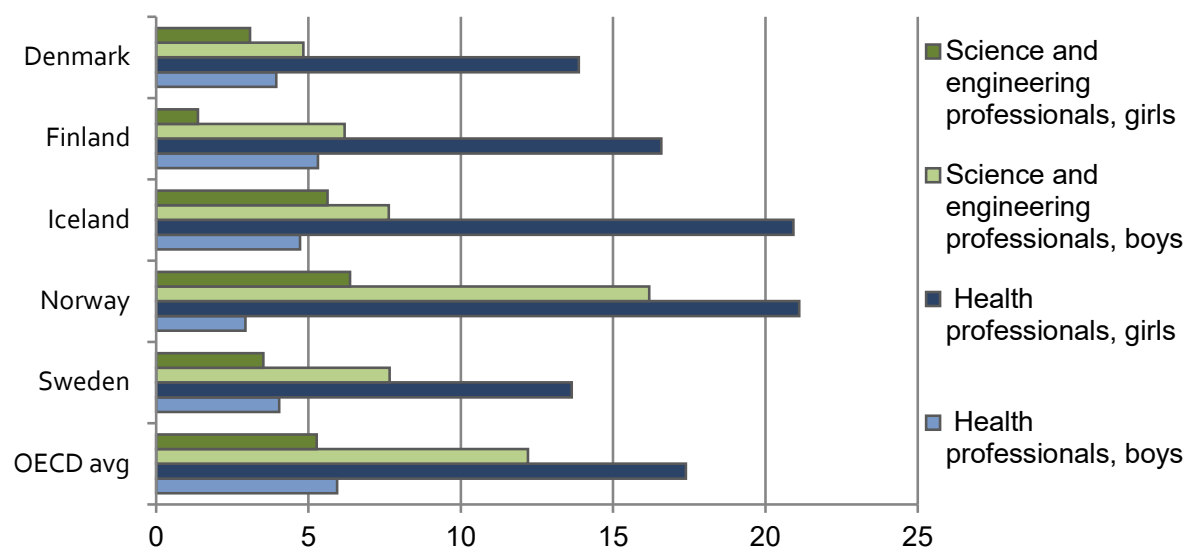

There were large gender differences in students' occupational preferences. Figure 6 shows that there in PISA 2015 were gender differences in students' choices of science careers in all of the Nordic countries. Boys more than girls expected to choose careers as engineers, and girls more than boys preferred health education. The same gender stereotype pattern was seen in PISA 2006 (Kjærnsli \& Lie 2011).

\subsubsection{Enjoyment, motivation, self-efficacy, and science career.}

To further explore how the different interest variables (enjoyment of learning science, instrumental motivation, and science self-efficacy) impact the likelihood that a student indicated that he or she imagined a science-related career, a logistic regression was run with the interest indices as independent variables and interest in a science career as the dependent variable. Because the career variable only had two values (yes or no/undecided), ordinary least squares linear regression was not suitable and therefore logistic regression, which is a more proper analysis for this kind of outcome variable, was performed. Even if the method was somewhat different from the regression analysis presented earlier, the purpose was the same - to determine the impact of different independent variables (the interest indices) on a dependent variable (in this case future occupation in science). The results of this analysis show that in contrast to science performance, and not very surprisingly, instrumental motivation seemed to be 
a highly important variable with regard to students imagining a future science-related occupation. Students scoring high on instrumental motivation were much more likely to indicate they imagined a science career when they are in their zos than students scoring low on instrumental motivation. The values in Table 5 are odds ratios (not the actual regression coefficients, but derived from these and shown in the table for the sake of simplicity), and these can be interpreted as follows. A value of 1 indicates that regardless of the value for the interest variables, the students were as likely to indicate a future scientific-related occupation. An odds ratio of 2, on the other hand, indicates that with a one-step increase in the interest variable, the student was twice as likely to indicate a future science-related occupation. For now, it can suffice with reading the table as follows. Significant coefficients above 1 mean that with a higher value on the interest index, the student was more likely to indicate that he or she considered a science-related occupation in the future. In line with findings from the previous regression analysis, the impact seems to have been stronger in 2006 than in 2015.

Table 5: Odds ratios from logistic regression with interest variables as independent variables and career expectation as the binary dependent variable for PISA 2006 and PISA 2015 in the Nordic countries

\begin{tabular}{|c|c|c|c|c|c|c|}
\hline \multirow[b]{2}{*}{ Country and year } & \multicolumn{2}{|c|}{ Instrumental motivation } & \multicolumn{2}{|c|}{$\begin{array}{c}\text { Enjoyment of learning } \\
\text { science }\end{array}$} & \multicolumn{2}{|c|}{ Science self-efficacy } \\
\hline & 2006 & 2015 & 2006 & 2015 & 2006 & 2015 \\
\hline Denmark & 2.8 & 2.3 & 1.5 & 1.4 & 1.2 & $0.9^{*}$ \\
\hline Finland & 2.8 & $2.4^{*}$ & 1.1 & 1.3 & 1.1 & 1.1 \\
\hline Iceland & 2.6 & $1.5^{*}$ & 1.5 & 1.4 & 1.1 & 1.0 \\
\hline Norway & 2.2 & $1.8 *$ & 1.3 & 1.3 & 1.1 & 1.0 \\
\hline Sweden & 2.3 & $1.8 *$ & 1.4 & 1.6 & 1.0 & 1.0 \\
\hline
\end{tabular}

Note: Statistically significant coefficients are indicated in italic, and when the difference between the coefficients within a country is significant between 2006 and 2015 this is indicated with an asterisk on the 2015 value.

Italic $=p<.01$, meaning the value is statistically significant at the $1 \%$ level, * $=$ change in coefficient between 2006 and 2015 is significant. Values are rounded to the nearest decimal to ease readability, and this is why the same value might be significant in one cell but not in another.

Both in 2006 and 2015, and in all Nordic countries, both instrumental motivation and enjoyment of learning science were significantly associated with the likelihood of students indicating a future occupation within the fields of science. Science self-efficacy had little impact on the likelihood that the student would be interested in a future career in science, and the effect of this variable was non-significant in all Nordic 
countries but Denmark (and here the effect was not very strong even if the value was significant), and the odds ratio was around 1 for most countries in both years.

We compared the size of the coefficients across the years, and in all countries except Denmark the coefficient for the instrumental motivation variable was significantly weaker $(p<.01)$ in 2015 than in 2006, although this variable was still the most important of the variables that were tested. In Denmark, on the other hand, the science self-efficacy coefficient was significantly weaker in 2015 , although in both years this coefficient was rather weak. For the other variables and the other countries, there were no significant differences between the logistic regression coefficients for 2006 and 2015 .

In summary, a student who enjoys science and recognises the value of science for their coming job is more likely to indicate a science occupation when asked what kind of job they think they will have in the future. This can be compared with the previous analyses where a student who enjoys science and trusts in their ability to solve sciencerelated questions (self-efficacy) is more likely to score well on the PISA test.

\subsection{Discussion}

Students' attitudes and motivation in relation to science are important for their understanding of the role of science and technology in a democratic society. They are also important for the students' choice of profession. It is therefore important to study how different factors such as instrumental motivation, enjoyment of learning science, and science self-efficacy depend on each other and if these variables can predict students' performance and their future science-related career expectations. This chapter will discuss the results and correlations between these variables and science performance in PISA 2006 and PISA 2015 for the Nordic countries and for the OECD countries.

The PISA definition of science literacy recognizes that a student's response to a science-related issue requires more than just skills and knowledge, and it also depends on how able and willing the student is to engage with the issue. The PISA 2015 assessment evaluated students' attitudes towards science in three areas through a questionnaire, including interest in science and technology, environmental awareness, and valuing scientific approaches to enquiry, all of which are considered core to the construct of scientific literacy. This means that the PISA study recognises the need for 
students to both understand and value science. In a democratic society, it is important that all citizens, independent of gender, age, or ethnicity, are competent to differ between fact and opinions and have the possibility to participate in well-informed discussions about social challenges.

The PISA 2015 data show that students' reported enjoyment of learning science has increased in all Nordic countries but Finland. In all Nordic countries except Denmark, there has also been an increase in students' instrumental motivation to learn science. There was also a smaller increase in students' science self-efficacy. Students in the Nordic countries seem to perceive science as more enjoyable and more valuable than they did just over a decade ago. There has also been an increase in enjoyment in several of the English-speaking countries such as the US, the UK, Australia, Ireland, and Canada. At the same time, the enjoyment was lower in 2015 than in 2006 in many countries in eastern and central Europe like Germany, France, the Netherlands, Slovenia, Slovakia, the Czech Republic, and Hungary. It seems as if students look at science in different ways in different parts of Europe, and one question is what the Nordic countries share with English-speaking countries that might explain the increased engagement in science.

At the same time, the PISA data show increased differences in the Nordic countries between boys and girls in terms of interest, self-efficacy, and career aspirations. This is an interesting finding because the Nordic countries are usually considered to be the most gender equal in the world (OECD, 2016a; Sørensen \& Dohn, 2016a). In addition, even though more students reported high self-efficacy and great interest in 2015 , there were increasing differences between students and there were a growing number of students reporting low enjoyment. We have on the one hand a growing number of students who are more engaged in school science, and on the other hand a growing number of students who feel more alienated.

The results of our analysis show that there were positive relationships in the Nordic countries between all of the three different interest variables and science performance when related to test score one by one in $\mathbf{2 0 1 5}$. The correlations were, however, weaker for all interest variables in 2015 compared to 2006. This means that even though there was an increase in enjoyment of learning science and science self-efficacy, these variables explained less of the results. There seemed to be new patterns in students' answers and a change in the reasons for why the students were interested in science. The regression analysis counted all variables together and showed that self-efficacy and enjoyment of learning science are important for science performance. Even though 
instrumental motivation was positively related to science performance itself, this effect disappeared when modelled together with enjoyment and self-efficacy. Students with high instrumental motivation performed better compared to lowly motivated students, but this can be explained by higher science self-efficacy and higher enjoyment of learning science among those students.

Expressed career expectations differed a lot among the OECD countries, but in all Nordic countries except Denmark there were more students who expected a sciencerelated career in 2015 compared to 2006. There might be differences in whether 15year-old students have made up their minds about possible careers. For example, in Denmark the majority of 15 -year-old students aim for a common start in upper secondary school, whereas Swedish students of that age choose between different theoretical and vocational programmes. The increase in students considering a science career in most Nordic countries is nevertheless important in the light of recent discussions about recruitment into the fields of science and technology and the concern about shortages of science graduates in the labour market (Gago et al., 2004). Students' instrumental motivation to learn science is clearly associated with an expectation of a science-related career. Enjoyment of learning science also seems to have some importance for students' interest in pursuing a science career. Self-efficacy, on the other hand, appears to have little or no impact on the likelihood that students expect a science-related career.

Although there are some differences across the Nordic countries and over time, the patterns generally look the same and suggest that enjoyment of learning science and science self-efficacy together are important for achievement in science, whereas instrumental motivation and enjoyment of learning science together are important reasons behind expecting a science-related job, which is in line with previous research (Areepattamannil, Freeman, \& Klinger, 2011; Wigfield \& Eccles, 2000). Consequently, all three aspects of interest assessed here appear to be important to monitor and to encourage. If society wants students who perform well in science as well as being interested in a science-related occupation, students' enjoyment of learning science seems especially important.

Another interesting finding is that for the 2015 data the models with all interest variables counted together explained less of the variation in performance and less of the variation in students who want to choose a science-related profession compared to 2006. This is in line with the results above where the change in the science score per unit of each index also decreased between 2006 and 2015. As shown here, there appear 
to be increasing differences between genders and between those with high and low interest in science. One example is boys who are more interested in science and have higher self-efficacy but who perform on the same level as girls on the PISA test in most of the Nordic countries. There seem to be new components behind students' attitudes that might explain why the models in general explain less of the variation.

\subsubsection{Implications}

There are positive signs in the Nordic countries when it comes to students' enjoyment of learning science and their science self-efficacy, and there an increased number of students expecting a career in science or technology-related occupations. The large differences between students when it comes to interest, motivation, and career expectations are nevertheless a challenge for modern societies. Research shows that students' interests and career expectations are deeply connected with their identity construction. It is not primarily about what to be, but about whom to be (Schreiner, 2005; Oskarsson, 2011; Teknikdelegationen, 2010). Socialisation into groups with those who think and act alike are strong and are reinforced by social media that is designed to help us to get "likes" and find "friends". Different groups of students seem to perceive science differently, and this could be one important explanation for the increasing differences between genders and between other groups of students that cannot be explained based on the available data, and thus further research is required.

Modern society is experiencing rapid changes with new technology influencing a greater part of our lives. Many jobs that students might have later in life do not even exist today, which means that students must be open to change and new trends in education and the labour market. The emerging picture is that enjoyment of learning science, instrumental motivation to learn science, and science self-efficacy have increased among many students in the Nordic countries. This indicates that the image of science is shifting. In the discussions about sustainability, the environment, and climate change, the focus is in many ways on new technologies like solar panels, windmills, and electric cars. Engineers, inventors, and entrepreneurs behind the brands that produce smartphones, electric cars, rockets, computer games, and social media platforms are well known from the media and in popular culture. In 2017, it was ten years since the iPhone was presented, and smartphones and social networks now provide new opportunities to retrieve information and new ways to hang out with and acquire friends. Students in the Nordic countries as well students in the English- 
speaking countries are diligent users of computers, smartphones, and social networks $(O E C D, 2017)$. All together, these developments might give students easier access to science and to technological achievements and the value of science may be more obvious in the everyday life of young people. This could be one explanation behind what seems like a shift in Nordic students' interest and self-belief in science and thus contribute to an understanding of why more students are thinking that science might be something for them.

\subsection{References}

Areepattamannil, S., Freeman, J. G., \& Klinger, D. A. (2011). Influence of motivation, selfbeliefs, and instructional practices on science achievement of adolescents in Canada. Social Psychology of Education, 14(2), 233-259. doi:10.1007/s11218-010-9144-9

Bandura, A. (2010). Self-Efficacy. In The Corsini Encyclopedia of Psychology. John Wiley \& Sons.

Bybee, R., \& McCrae, B. (2011). Scientific Literacy and Student Attitudes: Perspectives from PISA 2006 science. International journal of Science Education, 33(1), 7- 26.

Davidsson, Eva and Helene Sørensen (2010), Naturvidenskab: In Niels Egelund (ed.) PISA 2009 Danske unge i en international sammenligning Bind 1 - Resultatrapport, København, DPU.

Gago, J. M., Ziman, J., Caro, P., Constantinou, C., Davies, G., Parchmannn, I., . . Sjøberg, S. (2004). Europe Needs More Scientists: Report by the High Level Group on Increasing Human Resources for Science and Technology. Retrieved from http://europa.eu/rapid/press-release_IP04-444_en.htm

Jidesjö, A. (2012). En problematisering av ungdomars intresse för naturvetenskap och teknik i skola och samhälle: innehåll, medierna och utbildningens funktion. Norrköping: Department of Social and Welfare Studies, Linköping University.

Jidesjö, A., Oscarsson, M., Karlsson, K., \& Strömdahl, H. (2009). Science for all or science for some: What Swedish science students want to learn about in secondary science and technology and their opinions on science lessons. Nordina, 5(2), 213-229.

Kjærnsli, M., \& Lie, S. (2011). Students' preference for science careers: International comparisons based on PISA 2006. International Journal of Science Education, 33(1), 121-144.

Kjærnsli, M \& Jensen, Fredrik (red.) (2016). Stø kurs, Norske elevers kompetanse i naturfag, matematikk og lesing i PISA 2015. Oslo, Universitetsförlaget

Krapp, A., Hidi, S., \& Renninger, K. A. (1992). Interest, learning, and development. In K. A. Renninger, S. Hidi \& A. Krapp (Eds.) The Role of Interest in Learning and Development (pp. 325). Hillsdale, NJ: Lawrence Erlbaum Associates, Inc.

Krapp \& Prenzel (2011) PISA 2006 science. International Journal of Science Education, 33, 7-26. DOI: 10.1080/09500693.2010.518644

Lindahl, B. (2003). Lust att lära naturvetenskap och teknik? En longitudinell studie om vägen till gymnasiet. (Ph D), Göteborg: Acta Universitatis Gothoburgensis. 
Lyons, T. (2006). Different countries, same science classes: Students' experiences of school science in their own words. International Journal of Science Education, 28, 591-613. DOI: 10.1080/09500690500339621

Marsh, H. W., \& Craven, R. G. (2006). Reciprocal effects of self-concept and performance from a multidimensional perspective: Beyond seductive pleasure and unidimensional perspectives. Perspectives on psychological science, 1(2), 133-163.

Mullis, I. V. S., Martin, M. O., Foy, P., \& Hooper, M. (2016). TIMSS 2015 International Science Report.

Martin, M. O., Mullis, I. V. S., Foy, P., \& Stanco, G. (2012). TIMSS 2011 International Science Report.

OECD. (2007). PISA 2006: Science Competencies for Tomorrow's World, Vol. 1 Paris: OECD.

OECD. (2009). PISA 2006 Technical report. Paris: OECD.

OECD. (2016a). PISA 2015 Results (Volume I) Paris: OECD.

OECD. (2016b). PISA 2015 Technical Report. Paris: OECD.

OECD (2017), PISA 2015 Results (Volume V): Collaborative Problem Solving, OECD Publishing, Paris.

Osborne, J. and Dillon, J. 2008. Science education in Europe: Critical reflections. A report to the Nuffield Foundation, London: King's College

Oscarsson, M., Jidesjö, A., Karlsson, K. G., \& Strömdahl, H. (2009). Science in society or science in school: Swedish secondary teachers' beliefs about science and science lessons compared with what their students want to learn. Nordina, 5(1), 18-34.

Oskarsson, M. (2011). Viktigt - men inget för mig: ungdomars identitetsbygge och intresse för naturvetenskap. Linköpings universitet, Norrköping.

Oskarsson, M., Eliasson, N., \& Karlsson, K. G. (2017). Verkliga vardagssammanhang i årskurs 4 eller kontextlös kunskap i årskurs 8? Everyday life context in grade 4 or knowledge without context in grade 8. Nordic Studies in Science Education, 13(1), 36-51.

Pintrich, P. R., \& Schunk, D. H. (2002). Motivation in education: Theory, research and applications (2nd Ed.). New Jersey, NJ: Merril Prentice Hall.

Schreiner, C. (2005). Exploring a ROSE-garden. Norwegian youth's orientations towards scienceseen as signs of late modernity. University of Oslo, Oslo.

Skaalvik, E.M., Valas, H. (1999) Relations among Achievement, Self-Concept, and Motivation in Mathematics and Language Arts: A longitudinal study, Journal of Experimental Education, 67, 135-149.

Skolverket. (2016). TIMSS 2015: svenska grundskoleelevers kunskaper i matematik och naturvetenskap i ett internationellt perspektiv. Stockholm: Skolverket.

Sjøberg, S., \& Schreiner, C. (2010). The ROSE project: An overview and key findings. Retrieved from Oslo:

Sørensen, H. (2008). Piger og drenge svarer forskelligt - hvilke konsekvenser har det for undervisningen. I: Troelsen, R. P. \& Sølberg, J. (red). Den danske ROSE-undersøgelse, 41- 54. København: Institut for curriculumforskning, Danmarks Pædagogiske Universitetsskole, Århus Universitet. 
Sørensen, H. \& Dohn, N. B. (2016a). Elevernes holdninger og forventninger i forhold til naturfag. In V. T. Christensen (Ed.), PISA 2015 Danske unge i en international sammenligning (pp. 83-110). København: KORA.

Sørensen, H. \& Dohn, N. B. (2016b). Om naturfagene i PISA og i folkeskolen. In V. T.

Christensen (Ed.), PISA 2015 Danske unge i en international sammenligning (pp. 17-46). København: KORA.

Teknikdelegationen. (2010). Vändpunkt Sverige: ett ökat intresse för matematik, naturvetenskap, teknik och IKT. Stockholm: Fritzes.

Wigfield, A, \& Eccles, J. (2002). The development of competence beliefs, expectancies for success, and achievement values from childhood through adolescence. In A. Wigfield \& J. Eccles (Eds), Development of achievement motivation (pp 92-120). New York, NY: Academic Press.

Wigfield, A. \& Eccles, J. S. (2000). Expectancy-value theory of achievement motivation. Contemporary Educational Psychology, 25, 68-81.

Zimmerman, B. J., Bandura, A., \& Martinez-Pons, M. (1992). Self-motivation for academic attainment: The role of self-efficacy beliefs and personal goal setting. American educational research journal, 29(3), 663-676. 


\section{Nordic Council of Ministers \\ Nordens Hus \\ Ved Stranden 18 \\ DK-1061 Copenhagen K \\ www.norden.org}

\section{Northern Lights on TIMSS and PISA 2018}

The results from PISA 2015 and TIMSS 2015 were published in November and December 2016. All the Nordic countries participated in PISA.

Denmark, Finland, Norway and Sweden participated in TIMSS grade 4 and Norway and Sweden participated in TIMSS grade 8.

The Nordic countries have similarities but also differences, which makes it interesting and valuable to carry out analyses in a Nordic perspective. In this report researchers from all the Nordic countries have done in-depth analyses on different policy relevant themes based on the results presented in 2016. The purpose of this report has been to present policy relevant analyses of TIMSS and PISA in a way that is accessible for policy makers on different levels in the Nordic countries, with the aim to contribute to further development in the education area. 